\title{
Cell surface and gene expression regulation molecules in dystrophinopathy: $m d x$ vs. Duchenne
}

\author{
RICARDO FADIC
}

Unidad Neuromuscular, Departamento de Neurología, Facultad de Medicina, Pontificia Universidad Católica de Chile, Santiago, Chile

\begin{abstract}
Duchenne muscular dystrophy (DMD) is secondary to loss-of-function mutations in the dystrophin gene. The causes underlying the progression of DMD, differential muscle involvement, and the discrepancies in phenotypes among species with the same genetic defect are not understood. The $m d x$ mouse, an animal model with dystrophin mutation, has a milder phenotype. This article reviews the available information on expression of signaling-related molecules in DMD and $m d x$. Extracellular matrix proteoglycans, growth factors, integrins, caveolin-3, and neuronal nitric oxide synthase expression do not show significant differences. Calcineurin is inconsistently activated in $m d x$, which is associated with lack of cardiomyopathy, compared to the permanent calcineurin activation in $m d x$ /utrophin null mice that have a DMD-like cardiomyopathy. Levels of focal adhesion kinase (FAK) and extracellular regulated kinases (ERKs) differ among $m d x$ and DMD. Further work is needed to identify the point of discrepancy in these signaling molecules' pathways in dystrophynopathies.
\end{abstract}

Key terms: dystrophinopathy, signaling molecules, Duchenne muscular dystrophy.

Duchenne Muscular Dystrophy (DMD) is a muscle degenerative disease that is invariably fatal in humans. The primary cause of DMD is a mutation in the dystrophin gene leading to the absence of the corresponding RNA transcript and protein. It is believed that the absence of dystrophin leads to disruption of the dystrophinassociated protein complex, producing sarcolemmal instability that could render muscle fibers susceptible to necrosis (Matsumura et al., 1994). Although the histological pathology of dystrophic tissue has been well documented, little is known about the cascade of molecular events triggered by the absence of dystrophin that lead to muscle degeneration. Impairment of calcium homeostasis has been postulated as a key process but remains controversial (Gailly, 2002). The study of the specific sources of calcium signals involved in regulation of gene expression in skeletal muscle has been addressed only recently (Carrasco et al, 2004) and is beyond the scope of this article. There is an animal model of lack of dystrophin, the $m d x$ mouse. The mutants show mild clinical symptoms and are viable and fertile (Bulfield et al., 1984), in contrast to the fatal human disease. Different functional results in both species with the same genetic defect suggest that there is a distinct cellular response in each case. This article reviews what is known about differences in signal transduction and related molecules' expression in both model and our contribution to the subject. This text is organized in three segments, progressing from the outside of the muscle cell towards the inside: muscle surface and extracellular space, sarcolemma, and sarcoplasma. 


\section{EXTRACELLULAR SPACE}

It is known that in dystrophinopathies there is fibrosis in the interstitial space, that is characterized by the accumulation of extracellular matrix (ECM) material (Rampoldi et al., 1986). The ECM acts regulating growth factors and cytokines activation status and turnover: several of its molecules have signaling functions, therefore, it likely has an important role in muscle fibrosis and phenotype regulation. The ECM constituents that may participate regulating signaling are adhesion molecules, proteoglycans, and growth factors.

\section{Proteoglycans}

The total synthesis of proteoglycans, an ECM main constituent, is increased in $m d x$ mice (Cáceres et al., 2000). Muscle satellite cells from dystrophic mice have elevated levels of heparan sulphate proteoglycan receptors for fibroblast growth factor and synthesize ten times more sulfated glicosaminoglycans in culture than normal cells (Crisona et al., 1998). Biglycan, a small leucine-rich proteoglycan, shows increased expression in muscle from the dystrophic $m d x$ mouse (Bowe et al., 2000). We found that heparan sulfate proteoglycans are increased in muscle biopsies of DMD patients (Álvarez et al., 2002). Through SDS-PAGE analyses followed by specific identification of heparitinase-digested proteins with anti-Delta-heparan sulfate specific monoclonal antibodies, we observed an increase of three forms of heparan sulfate proteoglycans, corresponding to perlecan, syndecan-3, and glypican-1. Immunohistochemistry analyses indicated a differential localization for these proteoglycans: glypican-1 and perlecan were found mainly associated to ECM structures, while syndecan-3 was associated to muscle fibers (Álvarez et al., 2002). We also found that chondroitin/dermatan sulfate proteoglycans, decorine, and biglican are increased in DMD patients (Fadic et al., in preparation). The only information available about decorin and biglycan levels in DMD comes from gene expression profiles of skeletal muscle biopsies that demonstrate increases in their amount (Haslett et al., 2002). In both DMD patients and $m d x$ mice, there is a general increase in the amount of proteoglycans. Although further work is needed, it does not appear that there will be major differences between both species.

\section{Growth factors}

Three growth factors are related to muscle dystrophy: fibroblastic growth factor (FGF), transforming growth factor beta-1 (TGF- $\beta 1$ ) and its related molecule myostatin, and insulin-like growth factor-I (IGF-1). A heightened sensitivity of $m d x$ satellite cells to FGF was described (DiMario and Strohman, 1988). FGF levels in the $m d x$ extracellular matrix are higher than those in controls (Anderson et al., 1991; DiMario et al., 1989). FGF is co-expressed with myogenin in adjacent sections of focal muscle degeneration and repair in $m d x$ (Garrett and Anderson, 1995). Pre-treating myoblasts with FGF increases the percentage of fibers expressing dystrophin in host $m d x$ muscle (Kinoshita et al., 1996). FGFdeficient myoblasts have reduced motility that may contribute to the dystrophic changes in FGF2/FGF6/mdx triple-mutant mice (Neuhaus et al., 2003). Not much is known about FGF in DMD, but an elevated FGF level in the serum of patients was reported (D'Amore et al., 1994). In DMD, high TGF- $\beta 1$ immunoreactivity was expressed on muscle fibers and extracellular space. In other myopathies with endomysial fibrosis, however, TGF-beta 1 was seldom observed (Yamazaki et al., 1994). The TGF$\beta 1$ mRNA levels were greater in DMD patients than controls (Bernasconi et al., 1995). A similar result was reported in $m d x$ diaphragm (Gosselin et al., 2004). The failure of myoregeneration in DMD has been related to TGF- $\beta 1$ released from necrotic muscle fibers (Melone et al., 1999). Plasma TGF- $\beta 1$ level was significantly elevated in patients with DMD and congenital muscular dystrophy (CMD) but not in those with Becker muscular dystrophy (Ishitobi et al., 2000). Using expression microarrays analysis, overexpression of TGF- $\beta 1$ was found in DMD (Haslett et al., 2002). Myostatin, a TGF- $\beta$ family member, is a 
negative regulator of muscle growth. It was found to be down-regulated in dystrophic muscle (Zhu et al., 2000). Blockade of endogenous myostatin by using intraperitoneal injections of blocking antibodies resulted in an improvement of the phenotype of the $m d x$ mouse (Bogdanovich et al., 2002); a similar result was obtained with a myostatin-null $m d x$ mouse (Wagner et al., 2002). IGF-1 is known to promote proliferation and differentiation of muscle cells during growth and regeneration. At 810 weeks of age, significantly greater amounts of IGF-1 were found in plasma and hind limb muscles of $m d x$ mice with respect to controls. Such a difference was only just detectable and no longer statistically significant at 5 months of age. No differences were found in hepatic IGF-1 levels at either age (De Luca et al., 1999). Interestingly, IGF-1 expression significantly reduced the amount of fibrosis and myonecrosis in diaphragms from $m d x$ mice (Barton et al., 2002). Administration of IGF1 improved contractile function in $\mathrm{mdx}$ (Gregorevic et al., 2002). An increased expression of IGF-binding protein-5 in DMD fibroblasts in vitro was described (Melone et al., 2000). Expression microarrays were used to compare individual gene expression profiles of skeletal muscle biopsies from DMD patients and control patients. Bakay reported transcriptional up-regulation of both IGF-1 and IGF-2 in dystrophic muscle, however, the possible beneficial effects of the growth factors appear to be offset by transcriptional up-regulation of inhibitory IGF-binding proteins and regulators (Bakay et al., 2002). Additionally, an increase in expression of two IGF regulators: IGFbinding protein 4 (IGFBP4) and serine protease 11 was reported, without evidence of over-expression of IGFs (Haslett et al., 2002). No notable differences have been described in growth factors levels or functions of DMD and $m d x$.

\section{SARCOLEMMA}

The $\alpha 7 \beta 1$ integrin is the primary laminin receptor on myofibers. It has distinct functions during muscle development and contributes to muscle structural integrity. Immunofluorescence demonstrates an increase in $\alpha 7 \beta 1$ in patients with DMD and in $m d x$ mice. Analysis of RNA from both DMD patients and $m d x$ indicates that the increase in the $\alpha 7 \beta 1$ integrin is regulated at the level of $\alpha 7$ gene transcription (Hodges et al., 1997). Enhanced expression of the $\alpha 7$ chain in transgenic $m d x / u t r(-/-)$ mice, which lack both dystrophin and utrophin, alleviates many of the symptoms of dystrophy and compensates for the absence of the dystrophin- and utrophin-mediated linkage systems (Burkin et al., 2001). Nitric oxide (NO) is synthesized in skeletal muscle by neuronal-type NO synthase (nNOS), which is localized to sarcolemma of fast-twitch fibers associated to dystrophin. Synthesis of NO in active muscle opposes contractile force. Both $m d x$ mice and humans with DMD show a selective loss of nNOS protein and catalytic activity from muscle membranes (Brenman et al., 1995; Chang et al., 1996). nNOS is relocated to the interior of muscle cells, where it continues to produce $\mathrm{NO}$, but this does not contribute to dystrophy pathogenesis, as shown in nNOS-dystrophin null mice (Crosbie et al., 1998). Caveolae are vesicular invaginations of the plasma membrane and function as "message centers" for regulating signal transduction events. Caveolin-3, a muscle-specific caveolin-related protein, is the principal structural protein of caveolar membrane domains in skeletal muscle. The density of caveolae is increased in DMD and $m d x$ mouse (Repetto et al., 1999; Vaghy et al., 1998). Caveolin-3-overexpressing transgenic mice has a dystrophic phenotype (Galbiati et al., 2000). There is, then, no major difference between DMD and $m d x$ with regard to integrins, caveolin-3, and nNOS expression.

\section{SARCOPLASMA}

Ca2+/calmodulin-activated phosphatase calcineurin is ubiquitously expressed. Upon activation by $\mathrm{Ca} 2+$, calcineurin dephosphorylates nuclear factor of activated $\mathrm{T}$ cell (NFAT) transcription 
factors, leading to their nuclear translocation. Dilated cardiomyopathy is a common complication of DMD; in contrast, the $m d x$ mouse shows mildly dystrophic changes in the heart. The utrophindystrophin knockout (dko) mouse shows severe dystrophic changes in cardiac muscle that more closely resembles DMD cardiomyopathy than $m d x$ mouse. Interestingly, calcineurin and SAPK/p38MAPK signaling pathways were constantly activated in dko hearts, but the activation varied in $m d x$ hearts (Nakamura et al., 2001). Mice expressing enhanced muscle calcineurin activity $\left(\mathrm{CnA}^{*}\right)$ display elevated levels of utrophin around their sarcolemma. Crossing $\mathrm{CnA}^{*}$ mice with $m d x$ mice attenuates the dystrophic pathology (Chakkalakal et al., 2004). Deflazacort attenuates loss of dystrophic myofiber integrity in DMD muscle cells by upregulating the activity of calcineurin ( $\mathrm{St}$ Pierre et al., 2004).

There is very little information about extracellular regulated kinases (ERKs), a common endpoint for several signaling pathways, in both DMD and mdx. Levels of ERKs as well as phosphorylation states were elevated in the diaphragm and limb muscle of mdx mice compared with agematched control muscles (Lang et al., 2004). We found increased levels of total ERKs in both $m d x$ and DMD. However, the phosphorylated ERK form is only increased in DMD (Muñoz, Mezzano, Brandan and Fadic, submitted to PNAS USA). Focal adhesion kinase (FAK) is an important protein tyrosine kinase that mediates several integrin signaling pathways. There is no published information about FAK in dystrophinopathies. It is decreased in the $d y$ mouse, an animal model for the merosinnegative congenital muscular dystrophy (Sakuma et al., 2004). On the contrary, an increased level of activated FAK was found in muscle of $\alpha 7$ integrin-deficient mice (Saher and Hildt, 1999). We found no changes in FAK levels in $m d x$, but a reduced level in DMD (Muñoz, Mezzano, Brandan and Fadic, submitted to PNAS USA). Additional work is needed to identify the reasons for this divergence. Understanding the different cellular responses in both species to a similar injury may allow us to understand the pathogenesis of the muscle cell damage in this currently lethal condition.

\section{ACKNOWLEDGEMENTS}

Funded by Fondecyt \#1020699.

\section{REFERENCES}

ÁLVAREZ K, FADIC R, BRANDAN E (2002) Augmented synthesis and differential localization of heparan sulfate proteoglycans in Duchenne muscular dystrophy. J Cell Biochem 85: 703-713

ANDERSON JE, LIU L, KARDAMI E (1991) Distinctive patterns of basic fibroblast growth factor (bFGF) distribution in degenerating and regenerating areas of dystrophic (mdx) striated muscles. Dev Biol 147: 96109

BAKAY M, ZHAO P, CHEN J, HOFFMAN EP (2002) A web-accessible complete transcriptome of normal human and DMD muscle. Neuromuscul Disord 12 Suppl 1: S125-141

BARTON ER, MORRIS L, MUSARO A, ROSENTHAL N, SWEENEY HL (2002) Muscle-specific expression of insulin-like growth factor I counters muscle decline in mdx mice. J Cell Biol 157: 137-148

BERNASCONI P, TORCHIANA E, CONFALONIERI P, BRUGNONI R, BARRESI R, MORA M, CORNELIO F, MORANDI L, MANTEGAZZA R (1995) Expression of transforming growth factor-beta 1 in dystrophic patient muscles correlates with fibrosis. Pathogenetic role of a fibrogenic cytokine. J Clin Invest 96: 1137-1144

BOGDANOVICH S, KRAG TO, BARTON ER, MORRIS LD, WHITTEMORE LA, AHIMA RS, KHURANA TS (2002) Functional improvement of dystrophic muscle by myostatin blockade. Nature 420: 418-421

BOWE MA, MENDIS DB, FALLON JR (2000) The small leucine-rich repeat proteoglycan biglycan binds to alpha-dystroglycan and is upregulated in dystrophic muscle. J Cell Biol 148: 801-810

BRENMAN JE, CHAO DS, XIA H, ALDAPE K, BREDT DS (1995) Nitric oxide synthase complexed with dystrophin and absent from skeletal muscle sarcolemma in Duchenne muscular dystrophy. Cell 82: 743-752

BULFIELD G, SILLER WG, WIGHT PA, MOORE KJ (1984) X chromosome-linked muscular dystrophy (mdx) in the mouse. Proc Natl Acad Sci USA 81: 11891192

BURKIN DJ, WALLACE GQ, NICOL KJ, KAUFMAN DJ, KAUFMAN SJ (2001) Enhanced expression of the alpha 7 beta 1 integrin reduces muscular dystrophy and restores viability in dystrophic mice. J Cell Biol 152: 1207-1218

CÁCERES S, CUÉLLAR C, CASAR JC, GARRIDO J, SCHAEFER L, KRESSE H, BRANDAN E (2000) Synthesis of proteoglycans is augmented in dystrophic mdx mouse skeletal muscle. Eur J Cell Biol 79: 173181

CARRASCO MA, JAIMOVICH E, KEMMERLING U, HIDALGO C (2004) Signal transduction and gene 
expression regulated by calcium release from internal stores in excitable cells. Biol Res 37: 701-712

CHAKKALAKAL JV, HARRISON MA, CARBONETTO S, CHIN E, MICHEL RN, JASMIN BJ (2004) Stimulation of calcineurin signaling attenuates the dystrophic pathology in mdx mice. Hum Mol Genet 13: 379-388

CHANG WJ, IANNACCONE ST, LAU KS, MASTERS BS, MCCABE TJ, MCMILLAN K, PADRE RC, SPENCER MJ, TIDBALL JG, STULL JT (1996) Neuronal nitric oxide synthase and dystrophin-deficient muscular dystrophy. Proc Natl Acad Sci USA 93: 9142-9147

CRISONA NJ, ALLEN KD, STROHMAN RC (1998) Muscle satellite cells from dystrophic (mdx) mice have elevated levels of heparan sulphate proteoglycan receptors for fibroblast growth factor. J Muscle Res Cell Motil 19: 43-51

CROSBIE RH, STRAUB V, YUN HY, LEE JC, RAFAEL JA, CHAMBERLAIN JS, DAWSON VL, DAWSON TM, CAMPBELL KP (1998) mdx muscle pathology is independent of nNOS perturbation. Hum Mol Genet 7: 823-829

D'AMORE PA, BROWN RH, JR., KU PT, HOFFMAN EP, WATANABE $\mathrm{H}$, ARAHATA $\mathrm{K}$, ISHIHARA T, FOLKMAN J (1994) Elevated basic fibroblast growth factor in the serum of patients with Duchenne muscular dystrophy. Ann Neurol 35: 362-365

DE LUCA A, PIERNO S, CAMERINO C, COCCHI D, CAMERINO DC (1999) Higher content of insulin-like growth factor-I in dystrophic mdx mouse: Potential role in the spontaneous regeneration through an electrophysiological investigation of muscle function. Neuromuscul Disord 9: 11-18

DIMARIO J, BUFFINGER N, YAMADA S, STROHMAN RC (1989) Fibroblast growth factor in the extracellular matrix of dystrophic $(\mathrm{mdx})$ mouse muscle. Science 244: 688-690

DIMARIO J, STROHMAN RC (1988) Satellite cells from dystrophic $(\mathrm{mdx})$ mouse muscle are stimulated by fibroblast growth factor in vitro. Differentiation 39: 42-49

GAILLY P (2002) New aspects of calcium signaling in skeletal muscle cells: Implications in Duchenne muscular dystrophy. Biochim Biophys Acta 1600: 3844.

GALBIATI F, VOLONTE D, CHU JB, LI M, FINE SW, FU M, BERMÚDEZ J, PEDEMONTE $M$, WEIDENHEIM KM, PESTELL RG, MINETTI C, LISANTI MP (2000) Transgenic overexpression of caveolin-3 in skeletal muscle fibers induces a Duchenne-like muscular dystrophy phenotype. Proc Natl Acad Sci USA 97: 9689-9694

GARRETT KL, ANDERSON JE (1995) Colocalization of bFGF and the myogenic regulatory gene myogenin in dystrophic mdx muscle precursors and young myotubes in vivo. Dev Biol 169: 596-608

GOSSELIN LE, WILLIAMS JE, DEERING M, BRAZEAU D, KOURY S, MARTÍNEZ DA (2004) Localization and early time course of TGF-beta1 mRNA expression in dystrophic muscle. Muscle Nerve 30: 645-653

GREGOREVIC P, PLANT DR, LEEDING KS, BACH LA, LYNCH GS (2002) Improved contractile function of the mdx dystrophic mouse diaphragm muscle after insulin-like growth factor-I administration. Am J Pathol 161: 2263-2272

HASLETT JN, SANOUDOU D, KHO AT, BENNETT RR, GREENBERG SA, KOHANE IS, BEGGS AH, KUNKEL LM (2002) Gene expression comparison of biopsies from Duchenne muscular dystrophy (DMD) and normal skeletal muscle. Proc Natl Acad Sci USA 99: 15000-15005

HODGES BL, HAYASHI YK, NONAKA I, WANG W, ARAHATA K, KAUFMAN SJ (1997) Altered expression of the alpha7betal integrin in human and murine muscular dystrophies. J Cell Sci 110 ( Pt 22): 2873-2881

ISHITOBI M, HAGINOYA $\mathrm{K}$, ZHAO Y, OHNUMA A, MINATO J, YANAGISAWA T, TANABU M, KIKUCHI M, IINUMA K (2000) Elevated plasma levels of transforming growth factor beta1 in patients with muscular dystrophy. Neuroreport 11: 4033-4035

KINOSHITA I, VILQUIN JT, ROY T, TREMBLAY JP (1996) Successive injections in mdx mice of myoblasts grown with bFGF. Neuromuscul Disord 6: 187-193

LANG JM, ESSER KA, DUPONT-VERSTEEGDEN EE (2004) Altered activity of signaling pathways in diaphragm and tibialis anterior muscle of dystrophic mice. Exp Biol Med (Maywood) 229: 503-511

MATSUMURA K, TOME FM, COLLIN H, LETURCQ F, JEANPIERRE M, KAPLAN JC, FARDEAU M, CAMPBELL KP (1994) Expression of dystrophinassociated proteins in dystrophin-positive muscle fibers (revertants) in Duchenne muscular dystrophy. Neuromuscul Disord 4: 115-120

MELONE MA, PELUSO G, GALDERISI U, PETILLO O, COTRUFO R (2000) Increased expression of IGFbinding protein-5 in Duchenne muscular dystrophy (DMD) fibroblasts correlates with the fibroblastinduced downregulation of DMD myoblast growth: An in vitro analysis. J Cell Physiol 185: 143-153

MELONE MA, PELUSO G, PETILLO O, GALDERISI U, COTRUFO R (1999) Defective growth in vitro of Duchenne Muscular Dystrophy myoblasts: The molecular and biochemical basis. J Cell Biochem 76: 118-132

NAKAMURA A, HARROD GV, DAVIES KE (2001) Activation of calcineurin and stress activated protein kinase/p38-mitogen activated protein kinase in hearts of utrophin-dystrophin knockout mice. Neuromuscul Disord 11: 251-259

NEUHAUS $P$, OUSTANINA $S$, LOCH T, KRUGER $M$, BOBER E, DONO R, ZELLER R, BRAUN T (2003) Reduced mobility of fibroblast growth factor (FGF)deficient myoblasts might contribute to dystrophic changes in the musculature of FGF2/FGF6/mdx triplemutant mice. Mol Cell Biol 23: 6037-6048

RAMPOLDI E, MEOLA G, CONTI AM, VELICOGNA M, LARIZZA L (1986) A comparative analysis of collagen III, IV, laminin and fibronectin in Duchenne muscular dystrophy biopsies and cell cultures. Eur J Cell Biol 42: $27-34$

REPETTO S, BADO M, BRODA P, LUCANIA G, MASETTI E, SOTGIA F, CARBONE I, PAVAN A, BONILLA E, CORDONE G, LISANTI MP, MINETTI C (1999) Increased number of caveolae and caveolin-3 overexpression in Duchenne muscular dystrophy. Biochem Biophys Res Commun 261: 547-550

SAHER G, HILDT E (1999) Activation of c-Raf-1 kinase signal transduction pathway in alpha(7) integrindeficient mice. J Biol Chem 274: 27651-27657

SAKUMA K, NAKAO R, INASHIMA S, HIRATA M, KUBO T, YASUHARA M (2004) Marked reduction of focal adhesion kinase, serum response factor and myocyte enhancer factor $2 \mathrm{C}$, but increase in RhoA and myostatin in the hindlimb dy mouse muscles. Acta Neuropathol (Berl) 108: 241-249

ST-PIERRE SJ, CHAKKALAKAL JV, KOLODZIEJCZYK SM, KNUDSON JC, JASMIN BJ, MEGENEY LA (2004) Glucocorticoid treatment alleviates dystrophic 
myofiber pathology by activation of the calcineurin/ NF-AT pathway. Faseb J 18: 1937-1939

VAGHY PL, FANG J, WU W, VAGHY LP (1998) Increased caveolin-3 levels in mdx mouse muscles. FEBS Lett 431: 125-127

WAGNER KR, MCPHERRON AC, WINIK N, LEE SJ (2002) Loss of myostatin attenuates severity of muscular dystrophy in mdx mice. Ann Neurol 52: 832836
YAMAZAKI M, MINOTA S, SAKURAI H, MIYAZONO K, YAMADA A, KANAZAWA I, KAWAI M (1994) Expression of transforming growth factor-beta 1 and its relation to endomysial fibrosis in progressive muscular dystrophy. Am J Pathol 144: 221-226

ZHU X, HADHAZY M, WEHLING M, TIDBALL JG, MCNALLY EM (2000) Dominant negative myostatin produces hypertrophy without hyperplasia in muscle. FEBS Lett 474: 71-75 